\title{
Pendukung Keputusan Dalam Penentuan Produk Terbaik Pada PT Asuransi Jiwa Generali
}

\author{
Hardiyan $^{[1]}$, Rosiana Nur Hazizah $^{[2]}$ \\ Fakultas Teknologi Informasi, Universitas Bina Sarana Infromatika ${ }^{[1]}$ \\ J1. Kamal Raya No.18, Ring Road, Cengkareng, \\ Program Studi Sistem Informasi, STMIK Nusa Mandiri ${ }^{[2]}$ \\ J1. Daan Mogot No. 31, Tangerang \\ e-mail: hardiyan.hry@bsi.ac.id ${ }^{[1]}$,rosiana.hazizah24@gmail.com ${ }^{[2]}$
}

\begin{abstract}
Life insurance is a service business that provides guarantees to customers when they experience events that are at risk of losing their productivity to finance. However, most customers really regret having insurance customers because of their lack of understanding for insurance itself. Generali Life Insurance has several insurance products, so that there are obstacles in determining the best product interest, namely objectivity. The intended objectivity arises from the many products provided by Generali Life Insurance to reduce the complexity of the decision making process due to many alternative products. To help determine the best interest in the product using the Simple Additive Weigting (SAW) method. This method is a method by searching for weighted sums of performance ratings on each alternative and on each attribute. The Simple Additive Weighting (SAW) method can assist in decision making in a case, but the calculation by using this method only produces the greatest value that will be chosen as the best alternative.
\end{abstract}

Keywords-Insurance Products, SAW, Simple Additive Weighting

\section{PENDAHULUAN}

Kesehatan merupakan anugrah Allah SWT yang tidak ternilai harganya, oleh karena itu sepatutnya nikmat tersebut disyukuri. Kesehatan sudah merupakan kebutuhan pokok dalam hidup. Terwujudnya keadaan sehat adalah kehendak semua pihak. Meskipun sudah berhati-hati, orang tidak bisa secara mutlak menghindari bahaya sakit, kecelakaan, kematian, kebakaran, gempa bumi, pencurian dan tindakan criminal adalah keadaan bahaya yang mungkin dihadapi dalam hidup. Akibat yang timbul dari berbagai macam bahaya tersebut bisa berupa perasaan tidak menyenangkan sampai berupa malapetaka besar.

"Sistem merupakan kumpulan elemen yang saling berkaitan yang bertanggung jawab memproses masukan (input) sehingga menghasilkan keluaran (output)." (Frieyadie, 2016)

Meningkatnya permintaan masyarakat atas layanan kesehatan adalah tantangan bagi penyelenggara layanan kesehatan seperti rumah sakit, klinik, perusahaan asuransi dan bandan penyelenggara jaminan kesehatan. Institusi-institusi ini perlu menyiasati tantangan tersebut dengan meningkatkan program, sumber daya manusia dan manajemen sistem pembiayaan pemeliharaan kesehatan.

Asuransi kesehatan merupakan salah satu produk asuransi yang mempunyai beberapa kategori. Kategori utama asuransi kesehata adalah asuransi ketidakmampuan berpenghasilan (disabitity income insurance), asuransi biaya medis tradisional (traditional medical expanse insurance) dan managed care.

Beberapa produk di Asuransi Jiwa Generali antara lain adalah Santunan perawatan Harian, Asuransi Biaya Medis, Santunan Kesehatan Hari Tua, Jaminana Pemeliharaan Kesehatan Masyarakat, Santuan Dread Disase. Secara sederhana, produk Asuransi Jiwa Generali yang memberikan manfaat protensi sekaligus investasi dengan proposi alokasi dana yang diserahkan sepenuhnya kepada pemegang saham. Jika pada produk Asuransi Jiwa Generali premi yang dibayar oleh pemegang polis akan dibagi dua rekening yang terdiri dari rekening asuransi jiwa berjangka dan rekening unit (investasi).

Asuransi Jiwa Generali mengalami kendala dalam menentukan minat produk terbaik yaitu objektifitas. Objektifitas yang dimaksud muncul dari banyak produk yang disediakan oleh Asuransi Jiwa Generali untuk mengurangi kerumitan proses pengambilan keputusan akibat banyak alternative produk. Untuk membantu melakukan penentuan minat produk terbaik tersebut menggunakan metode Simple Additive Weigting (SAW).

\section{TINJAUAN PUSTAKA}

\section{A. Sistem Penunjang Keputusan}

Sistem Pendukung keputusan (SPK) yaitu sebuah sistem berbasis komputer yang adaptif, fleksibel dan interaktif yang digunakan untuk memecahkan masalah-masalah tidak terstuktur sehingga meningkatkan nilai keputusan yang diambil (Liesdiana \& Mauliana, 2017).

Mengemukakan keputusan bahwa Terdapat dus model pengambilan keputusan, yaitu model sistem tertutup dan model sistem terbuka (Frieyadie, 2016). 


\section{1) Model Sistem Tertutup}

Model sistem tertutup dilandasi asumsi bahwa keputusan dapat diambil tanpa campur tangan dari lingkungan (luar) sistem, karena sistem pengmbil keputusan tidak dipengaruhi oleh lingkungan. Dalam hal ini sistem pengmbilan keputusan dianggap :

- Mengetahui semua alternatif tindakan untuk menggapai permaslahan dengan segala konsekensinya.

- Memiliki metode untuk menyusun alternatifalternatif sesuai prioritasnya.

- Dapat memilih/menetapkan alternatif yang paling menguntungkan, misalnya dari segi laba, manfaat, dan lain-lain.

\section{2) Model Sistem Terbuka}

Model sistem terbuka dilandasi asumsi bahwa sistem pengambil keputusan dan lingkungan memiliki hubungan saling berpengaruh. Keputusan yang diambil akan berdampak terhadap lingkungan dan sebalikya lingkungan juga berpengaruh terhadap sistem pengambilan keputusan. Dalam hal ini sistem pengambilan keputusan dianggap :

- Hanya mempengaruhi sebagian saja dari alternatifalternatif untuk menangani permasalahan dengan segala konsekensinya.

- Hanya dapat menyajikan sejumlah alternatif yang baik untuk menangani permasalahan, tetapi tidak dapat memilih/menetapkan alternatif yang paling menguntungkan.

- Sekedar mempersilahkan pemilihan alternatif terbaik untuk dilakukan oleh pijak diluar sistem sesuai dengan aspirasinya.

\section{B. Sample Additive Weight (SAW)}

Metode Simple Additive Weight (SAW), sering juga dikenal dengan istilah metode penjumlahan terbobot. Konsep dasar metode Simple Additive Weight (SAW) adalah mencari penjumlahan terbobot dari rating kinerja pada setiap alternatif pada semua atribut. Metode Simple Additive Weight (SAW) dapat membantu dalam pengambilan keputusan suatu kasus, akan tetapi perhitungan dengan menggunakan metode ini hanya yang menghasilkan nilai terbesar yang akan terpilih sebagai alternatif yang terbaik. (Hismawati \& Hardiyan, 2018)

Keunggulan dari metode Simple Additive Weight (SAW) dibanding dengan metode sistem keputusan yang lain terletak pada kemauan dalam menentukan penelitian secara lebih tepat karena didasarkan pada nilai kriteria dan bobot tingkat kepentingan yang dibutuhkan. Metode SAW merupakan metode menentukan nilai bobot pada setiap kriteria untuk menentukan alternatif optimal (Susianti \& Wasiyanti, 2017)

$$
r_{i j}=\left\{\begin{array}{l}
\frac{x_{i j}}{\operatorname{Max}_{i} x_{i j}} \text { Jika } \mathrm{j} \text { adalah atribut keuntungan (benefit) } \\
\frac{\operatorname{Min}_{i} x_{i j}}{x_{i j}} \text { Jika } \mathrm{j} \text { adalah atribut keuntungan (cost) }
\end{array}\right.
$$

$\begin{array}{ll}\text { Dimana: } & \\ \text { Rij } & =\text { Rating Kinerja Ternormalisasi } \\ \text { Maxij } & =\text { Nilai maksimum dari setiap baris dan } \\ & \text { kolom } \\ \text { Minij } & =\text { Nilai minimum dari setiap baris dan kolom } \\ \text { Xij } & =\text { Baris dan kolom dari matriks }\end{array}$

Dengan Rij adalah rating kinerja ternormalisasi dari alternative Ai pada atribut

$\mathrm{Cj} ; 1,2, \ldots \mathrm{m}$ dan $\mathrm{j}=1,2, \ldots \mathrm{n}$

$V_{i}=\sum_{j=1}^{n} w_{j} r_{i j}$

Nilai Vi yang lebih besar mengindikasikan bahwa alternatif Ai lebih terpilih.

$\mathrm{V}_{\mathrm{i}} \mathrm{i}=$ Nilai akhir dari alternatif

$\mathrm{W}_{-} \mathrm{i}=$ Bobot yang telah ditentukan

$\mathrm{R}_{\mathrm{j} \mathrm{j}}=$ Normalisasi matriks

Nilai yang lebih besar mengindikasikan bahwa alternatif lebih terpilih. Metode Simple Additive Weighting (SAW) disarankan untuk menyelesaikan masalah penyeleksian dalam sistem pengambilan keputusan multi proses. Metode Simple Additive Weighting (SAW) merupakan metode yang banyak digunakan dalam pengambilan keputusan yang memiliki banyak atribut. (Frieyadie, 2016).

Ada beberapa langkah dalam penyelesaian metode Simple Additive Weighting (SAW) sebagai berikut :

- Menentukan kriteria-kriteria yang dijadikan acuan dalam pendukung keputusan yaitu $\mathrm{Ci}$.

- Menentukan rating kecocokan setiap alternatif pada setiap kriteria.

- Membuat matriks keputusan berdasarkan kriteria (C_i).

- Kemudian melakukan normalisai matriks berdasarkan persamaan yang disesuaikan dengan jenis atribut (atribut keuntungan maupun atribut biaya) sehingga diperoleh matriks ternormalisai $\mathrm{R}$.

- Hasil akhir diperoleh dari proses perangkaian yaitu penjumlahan dari perkalian matriks ternormalisasi $\mathrm{R}$ dengan vector bobot sehingga diperoleh nilai terbesar yang dipilih sebagai alternatis terbaik (A_i) sebagai solusi.

\section{Keputusan Pembelian}

Definisi keputusan pembelian sabran (2009)" Dalam tahapan evaluasi, konsumen membentuk preferensi antara merek dalam kumpulan pilihan, konsumen membentuk maksud untuk membeli merek yang paling disukai”. (Suparwo, Riana, \& Sari, 2017)

"Keputusan pembelian konsumen adalah proses pemecahan masalah di mana penyajian ulang kognitif konsumen atas suatu 
masalah iala kunci untuk memahami proses tersebut".(Suparwo et al., 2017)

Tahapan-tahapan keputusan pembelian diantaranya :

1) Pengenalan masalah

Proses pembelian dimulai ketika pembelian mengenali masalah atau kebutuhan. Kebutuhan tersebut dapat dicetuskan oleh rangsangan internal atau eksternal. Para pemasar perlu mengidentifikasi keadaan yang memicu kebutuhan tersebut.

2) Pencarian informasi

Konsumen yang terangsang kebutuannya akan terdorong untuk mencari infromasi yang lebih banyak. Kita dapat membaginya ke dalam dua level rangsangan. Situaso pencarian infromasi yang lebih ringan dinamakan penguatan perhatian. Pada level itu orang hanya sekedar lebih peka terhadap informasi produk.

\section{3) Evaluasi alternatif}

Bagaimana konsumen mengolah infromasi merek yang bersaing dan membuat penilaian akhir. Tidak ada proses evaluasi tunggal sederhana yang digunakan oleh semua konsumen atau olehh suatu konsumen dalam semua situasi pembelian. Terdapat beberapa proses evaluasi keputusan, dan model-model yang terbaru memandangan proses evaluasi konsumen sebagai proses yang berorientasi kognitif. Yaitu model tersebut menganggap konsumen membentuk penilaian atas produk dengan sadar dan rasional.

\section{4) Keputusan Pembelian}

Dalam tahap evaluasi, para konsumen membentuk prefensinatas merek-merek yang ada di dalam kumpulan pilihan. Konsumen tersebut juga dapat membentuk nilai untuk membeli merek yang paling disukai. Dalam melaksanakan niat pembelian, konsumen tersebut dapat membuat lima sub keputusan merek (merek A), keputusan pemasok (deale 2), keputusan kualitas (satu computer), keputusan waktu (akhir pecan), dan keputusan metode pembayaran (kartu kredit). Pembelian barang kebutuhan sehari-hari melibatkan lebih sedikit keputusan dan lebih sedikt pertimbangan.

\section{5) Perilaku pasca pembelian}

Setelah membeli produk, konsumen akan mengalami level kepuasan atau ketidakpuasan tertentu. Tugas pemasar tidak berakhir begitun saja ketika produk dibeli. Para pemasar harus memantau kepuasan pascapembalian dan pemakaian produk pascapembelian.

\section{Metode PENELITIAN}

Penelitian ini dilakukan dengan cara mengumpulkan datadata yang berhubungan dengan permasalahan yang dibahas sehingga dapat membantu menyelesaikan permasalahan, (Nuraeni, 2018).

Dalam penelitian ini, diperlukan beberapa langkah untuk mencapai tujuan yang telah ditetapkan sebelumnya. Adapun langkah-langkah penyusunan penelitian yang dilakukan pada
Gambar dibawah ini.

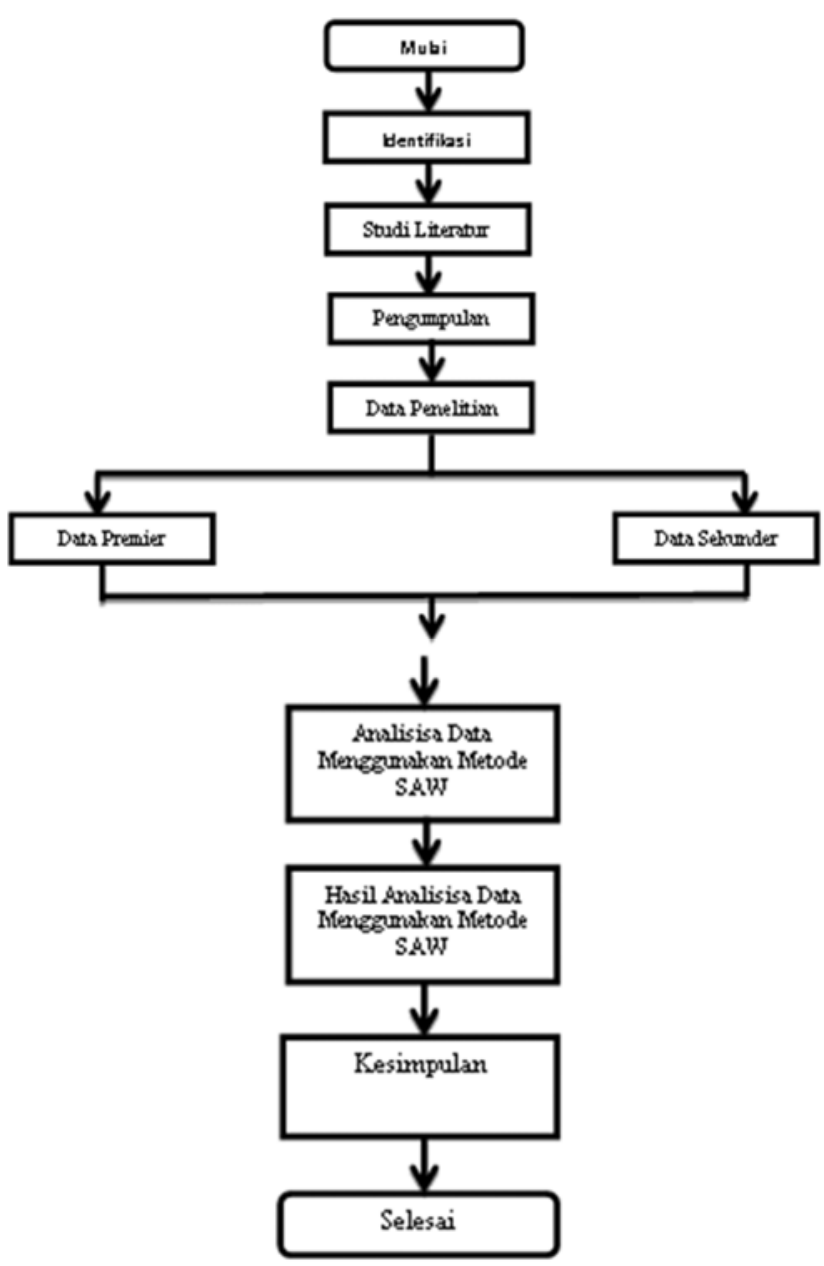

Gambar 1. Workflow Penelitian

\section{A. Instrumen Penelitian}

Instrumen penelitian dapat disimpulkan " Semua alat yang digunakan untuk mengumpulkan, mengolah, menganalisa dan menyajikan data-data secara sistematis serta objektif dengan tujuan memecahkan suatu persoalan atau menguji suatu hipotesis". (Hismawati \& Hardiyan, 2018)

Instrumen penelitian yang digunakan penulis dalam penelitian ini sebagai berikut :

\section{1) Data kualitatif}

Penulis menggunakan data kualitatif dalam menganalisis suatu masalah dalam bentuk nilai yang didasarkan pada hasil pengolahaan dan peniliaian dari bagian HRD dan Manajer terhadap penentuan produk terbaik.

2) Kuesioner

Kuesioner dirancang sendiri oleh penulis dan dikembangkan dari teori menggunakan skala likert. Kuesioner tersebut diisi oleh responden yaitu Manajer di PT. 
Asuransi Jiwa Generali.

\section{B. Populasi dan Sampel Penelitian}

Populasi adalah wilayah generalisasi yang terdiri atas : obyek dan subyek yang mempunyai kualitas dan karakteristik tertentu yang ditetapkan oleh penelitian untuk dipelajari, kemudian ditarik kesimpulannya (Rusdiansyah, 2017). Populasi dalam penelitian ini adalah penentuan produk terbaik pada PT. Asuransi Jiwa Generali. Berdasarkan data bulan 3 Agustus 2018 dimana jumlah produk pada PT. Asuransi Jiwa Generali berjumlah 25 produk.

Penulis melakukan pengumpulan data pada PT. Asuransi Jiwa Generali dengan cara pengambilan sampel (sampling), yaitu pemilihan sejumlah item tertentu dari populasi yang ada dengan tujuan mempelajari sebagai item tersebut sehingga dapat mewakili seluruh item yang ada. Semua item-item populasi mempunyai kesempatan (probabilitas) yang sama untuk terpilih menjadi item sampel. Teknik sampling yang penulis gunakan yaitu Simple random sampling.

\section{HASIL DAN PEMBAHASAN}

PT. Asuransi Jiwa Generali sebagai populasi yang akan dijadikan subjek penelitian. Adapun produk-produk yang terdapat dalam perusahaan, terlihat pada Tabel I dibawah ini.

TABEL I. POPULASI PENELITIAN

\begin{tabular}{|c|c|}
\hline Nama Produk & Kode Produk \\
\hline IPrime & A1 \\
\hline Iplan & A2 \\
\hline iPLAN Syariah & A3 \\
\hline UBRich & A4 \\
\hline Gemilang & A5 \\
\hline Generali Flexi Optima & A6 \\
\hline We Flexi Pro & A7 \\
\hline Global Medical Plan & A8 \\
\hline GENSafe & A9 \\
\hline Asuransi Perlindungan Kredit & A10 \\
\hline Asuransi Kecelakaan Diri Mikro & A11 \\
\hline Asuransi Kecelakaan Diri & A12 \\
\hline Asuransi Jiwa Berjangka Kumpulan & A13 \\
\hline Asuransi Cacat Tetap Total Kumpulan & A14 \\
\hline $\begin{array}{l}\text { Asuransi Kematian dan Cacat Tetap Karena } \\
\text { Kecalakaan Kumpulan }\end{array}$ & A15 \\
\hline $\begin{array}{l}\text { Asuransi Perwatan Rumah Sakit dan Perbedaan } \\
\text { Kumpulan }\end{array}$ & A16 \\
\hline Asuransi Rawat Jalan Kumpulan & A17 \\
\hline Asuransi Perawatan Gigi Kumpulan & A18 \\
\hline Asuransi Kacamata Kumpulan & A19 \\
\hline iPENSION & A20 \\
\hline iDARE & A21 \\
\hline UB Pro Plus & $\mathrm{A} 22$ \\
\hline Ipro & A23 \\
\hline Provesta Optimum & A24 \\
\hline VIP Pro & A25 \\
\hline
\end{tabular}


TABEL II. SAMPEL PENELITIAN

\begin{tabular}{|c|c|c|}
\hline Nama Produk & $\begin{array}{c}\text { Kode } \\
\text { Produk }\end{array}$ & $\begin{array}{c}\text { Kategori } \\
\text { Produk }\end{array}$ \\
\hline IPrime & A1 & Individu \\
\hline Iplan & A2 & Individu \\
\hline iPLAN Syariah & A3 & Individu \\
\hline UBRich & A4 & Individu \\
\hline Gemilang & A5 & Individu \\
\hline Generali Flexi Optima & A6 & Individu \\
\hline We Flexi Pro & A7 & Individu \\
\hline Global Medical Plan & A8 & Individu \\
\hline GENSafe & A9 & Individu \\
\hline Asuransi Perlindungan Kredit & A10 & Individu \\
\hline Asuransi Kecelakaan Diri Mikro & A11 & Individu \\
\hline Asuransi Kecelakaan Diri & A12 & Individu \\
\hline $\begin{array}{lll}\text { Asuransi } & \text { Jiwa } & \text { Berjangka } \\
\text { Kumpulan } & & \\
\end{array}$ & A13 & Grup \\
\hline $\begin{array}{l}\text { Asuransi Cacat } \text { Tetap } \\
\text { Kumpulan }\end{array}$ & A14 & Grup \\
\hline $\begin{array}{lll}\text { Asuransi } & \text { Kematian } & \text { dan Cacat } \\
\text { Tetap } & \text { Karena } & \text { Kecelakaan } \\
\text { Kumpulan } & \\
\end{array}$ & A15 & Grup \\
\hline $\begin{array}{l}\text { Asuransi Perwatan Rumah Sakit } \\
\text { dan Perbedaan Kumpulan }\end{array}$ & A16 & Grup \\
\hline Asuransi Rawat Jalan Kumpulan & A17 & Grup \\
\hline $\begin{array}{lll}\text { Asuransi } & \text { Perawatan } & \text { Gigi } \\
\text { Kumpulan } & & \\
\end{array}$ & A18 & Grup \\
\hline Asuransi Kacamta Kumpulan & A19 & Grup \\
\hline iPENSION & A20 & Grup \\
\hline iDARE & $\mathrm{A} 21$ & Individu \\
\hline UB Pro Plus & $\mathrm{A} 22$ & Individu \\
\hline iPRO & $\mathrm{A} 23$ & Individu \\
\hline Provesta Optimum & A24 & Individu \\
\hline VIP Pro & $\mathrm{A} 25$ & Individu \\
\hline
\end{tabular}

TABEL III. PENENTUAN KRITERIA

\begin{tabular}{|c|c|}
\hline Kode & Kriteria \\
\hline $\mathrm{C} 1$ & Premi \\
\hline $\mathrm{C} 2$ & Pertanggungan \\
\hline $\mathrm{C} 3$ & Jangka Premi \\
\hline $\mathrm{C} 4$ & Santunan \\
\hline $\mathrm{C} 5$ & Masa Pertanggungan \\
\hline
\end{tabular}

TABEL IV. PENGGOLONGAN KRITERIA

\begin{tabular}{|l|c|c|}
\hline \multicolumn{1}{|c|}{ Kriteria } & $\begin{array}{c}\text { Keuntungan } \\
\text { (Benefit) }\end{array}$ & Biaya (Cost) \\
\hline Premi & $\checkmark$ & \\
\hline Pertanggungan & $\checkmark$ & \\
\hline Jangka Premi & & $\checkmark$ \\
\hline Santunan & & $\checkmark$ \\
\hline Masa Pertanggungan & & $\checkmark$ \\
\hline
\end{tabular}

1) Selanjutnya memberikan nilai bobot pada masingmasing kriteria

TABEL V. PENENTUAN NILAI

\begin{tabular}{|c|c|c|}
\hline Kode & Range & Bobot \\
\hline C1 & 30 & 0,30 \\
\hline C2 & 25 & 0,25 \\
\hline C3 & 20 & 0,20 \\
\hline C4 & 15 & 0,15 \\
\hline C5 & 10 & 0,10 \\
\hline
\end{tabular}

Adapun kriteria pembobotan yang dilakukan penulis dalam penelitian penentuan produk terbaik, yaitu sebagai berikut :

a) Kriteria Premi

TABEL VI. PENELITIAN PREMI

\begin{tabular}{|c|l|c|}
\hline Penilaian Hasil Kerja & \multicolumn{1}{|c|}{ Keterangan } & Nilai \\
\hline $1-20$ & Sangat Rendah & 1 \\
\hline $21-40$ & Rendah & 2 \\
\hline $41-60$ & Sedang & 3 \\
\hline $61-80$ & Tinggi & 4 \\
\hline $81-100$ & Sangat Tinggi & 5 \\
\hline
\end{tabular}

b) Kriteria Pertanggungan

TABEL VII. PENELITIAN PERTANGGUNGAN

\begin{tabular}{|c|l|c|}
\hline Penilaian Hasil Kerja & \multicolumn{1}{|c|}{ Keterangan } & Nilai \\
\hline $1 \%-20 \%$ & Sangat Rendah & 1 \\
\hline $21 \%-40 \%$ & Rendah & 2 \\
\hline $41 \%-60 \%$ & Sedang & 3 \\
\hline $61 \%-80 \%$ & Tinggi & 4 \\
\hline $81 \%-100 \%$ & Sangat Tinggi & 5 \\
\hline
\end{tabular}

c) Kriteria Jangka Premi

TABEL VIII. PENELITIAN JANGKA PREMI

\begin{tabular}{|c|l|c|}
\hline Penilaian Hasil Kerja & \multicolumn{1}{|c|}{ Keterangan } & Nilai \\
\hline $1-20$ & Sangat Rendah & 1 \\
\hline $21-40$ & Rendah & 2 \\
\hline $41-60$ & Sedang & 3 \\
\hline $61-80$ & Tinggi & 4 \\
\hline $81-100$ & Sangat Tinggi & 5 \\
\hline
\end{tabular}

d) Kriteria Santunan

TABEL IX. PENELITIAN SANTUNAN

\begin{tabular}{|c|l|c|}
\hline Penilaian Hasil Kerja & \multicolumn{1}{|c|}{ Keterangan } & Nilai \\
\hline $1-20$ & Sangat Rendah & 1 \\
\hline $21-40$ & Rendah & 2 \\
\hline $41-60$ & Sedang & 3 \\
\hline $61-80$ & Tinggi & 4 \\
\hline $81-100$ & Sangat Tinggi & 5 \\
\hline
\end{tabular}


e) Kriteria Masa Pertanggungan

TABEL X. PENELITIAN MASA PERTANGGUNGAN

\begin{tabular}{|c|l|c|}
\hline Penilaian Hasil Kerja & \multicolumn{1}{|c|}{ Keterangan } & Nilai \\
\hline $1-20$ & Sangat Rendah & 1 \\
\hline $21-40$ & Rendah & 2 \\
\hline $41-60$ & Sedang & 3 \\
\hline $61-80$ & Tinggi & 4 \\
\hline $81-100$ & Sangat Tinggi & 5 \\
\hline
\end{tabular}

2) Menentukan Nilai Rating Kecocokan dari setiap produk pada setiap kriteria.

TABEL XI. RATING KECOCOKAN

\begin{tabular}{|l|l|r|r|r|r|c|}
\hline \multirow{2}{*}{ No } & \multirow{2}{*}{$\begin{array}{l}\text { Yode } \\
\end{array}$} & \multicolumn{5}{|c|}{ Kriteria } \\
\hline & & 5 & 5 & 5 & 4 & 2 \\
\hline & & 5 & 5 & 5 & 3 & 1 \\
\hline & & 4 & 4 & 3 & 3 & 1 \\
\hline & & 4 & 4 & 4 & 4 & 1 \\
\hline & & 4 & 4 & 3 & 3 & 1 \\
\hline & & 4 & 4 & 4 & 4 & 1 \\
\hline & & 4 & 4 & 4 & 3 & 2 \\
\hline & & 4 & 4 & 4 & 4 & 2 \\
\hline & & 4 & 4 & 3 & 3 & 1 \\
\hline & & 5 & 5 & 5 & 5 & 4 \\
\hline & & 5 & 5 & 4 & 4 & 1 \\
\hline & & 4 & 5 & 3 & 3 & 2 \\
\hline & & 4 & 5 & 5 & 5 & 2 \\
\hline & & 4 & 4 & 3 & 3 & 1 \\
\hline & & 4 & 5 & 5 & 5 & 2 \\
\hline & & 4 & 4 & 5 & 5 & 4 \\
\hline & & 5 & 5 & 5 & 5 & 5 \\
\hline & & 5 & 4 & 4 & 4 & 3 \\
\hline & & 4 & 5 & 4 & 4 & 4 \\
\hline & & 5 & 4 & 5 & 4 & 4 \\
\hline & & 4 & 5 & 3 & 3 & 3 \\
\hline & & 4 & 4 & 4 & 5 & 3 \\
\hline & & 4 & 4 & 5 & 3 & 1 \\
\hline & & 4 & 4 & 5 & 4 & 3 \\
\hline & & 4 & 4 & 5 & 4 & 5 \\
\hline
\end{tabular}

Keterangan Kriteria:

PR : Premi

PT : Pertanggungan

JP : Jangka Premi

ST : Santunan

MP : Masa Pertanggungan

3) Membuat Matiks Keputusan yang dibentuk dari Tabel Rating Kecocokan, sebagai berikut :

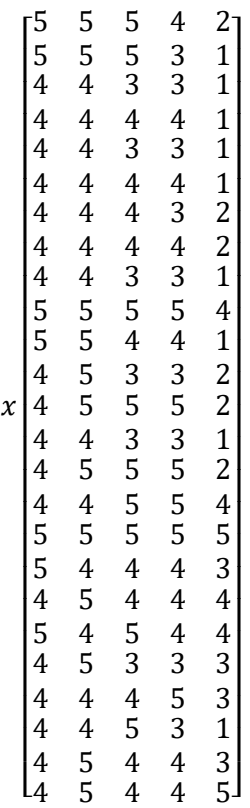

Pertama-tama melakukan normalisasi matriks $\mathrm{X}$ dan kemudian hasil dari normalisasi tersebut dibuat dalam matriks ternormalisasi $(\mathrm{R})$ sebagai berikut :

$$
\left[\begin{array}{ccccc}
1,0 & 1,0 & 0,6 & 0,75 & 0,5 \\
1,0 & 1,0 & 0,6 & 1,0 & 1,0 \\
0,8 & 0,8 & 1,0 & 1,0 & 1,0 \\
0,8 & 0,8 & 0,75 & 0,75 & 1,0 \\
0,8 & 0,8 & 1,0 & 1,0 & 1,0 \\
0,8 & 0,8 & 0,75 & 0,75 & 1.0 \\
0,8 & 0,8 & 0,75 & 1,0 & 0,5 \\
0,8 & 0,8 & 0,75 & 0,75 & 0,5 \\
0,8 & 0,8 & 1,0 & 1,0 & 1,0 \\
1,0 & 1,0 & 0,6 & 0,75 & 0,75 \\
1,0 & 1,0 & 0,75 & 0,75 & 1,0 \\
0,8 & 1,0 & 1,0 & 1,0 & 0,5 \\
0,8 & 1,0 & 0,6 & 0,6 & 0,5 \\
0,8 & 0,8 & 1,0 & 1,0 & 1,0 \\
0,8 & 1,0 & 0,6 & 0,6 & 0,5 \\
0,8 & 0,8 & 0,6 & 0,6 & 0,25 \\
1,0 & 1,0 & 0,6 & 0,6 & 0,2 \\
1,0 & 0,8 & 0,75 & 0,75 & 0,33 \\
0,8 & 1,0 & 0,75 & 0,75 & 0,25 \\
1,0 & 0,8 & 0,6 & 0,6 & 0,25 \\
0,8 & 1,0 & 1,0 & 1,0 & 0,33 \\
0,8 & 0,8 & 0,75 & 0,6 & 0,33 \\
0,8 & 0,8 & 0,6 & 1,0 & 1,0 \\
0,8 & 1,0 & 0,75 & 0,75 & 0,33 \\
0,8 & 1,0 & 0,75 & 0,75 & 0,2
\end{array}\right]
$$

4) Langkah terakhir adalah proses pencarian perangkingan atau nilai terbaik dengan memasukan setiap kriteria dan nilai bobot yang digunakan dalam perangkingan 
yaitu $\mathrm{W}=[0,30,250,20,150,1\rceil$ maka proses perangkingan sebagai berikut :

$$
V_{i}=\sum_{j=1}^{n} w_{j} r_{i j}
$$

Nilai Vi yang lebih besar mengindikasikan bahwa alternatif Ai lebih terpilih.

$$
\begin{array}{ll}
V_{i} & =\text { Nilai akhir dari alternatif } \\
W_{i} & =\text { Bobot yang telah ditentukan } \\
R_{j i} & =\text { Normalisasi matriks }
\end{array}
$$

\begin{tabular}{|c|c|c|}
\hline Nama Produk & $\begin{array}{c}\text { Kode } \\
\text { Produk }\end{array}$ & $\begin{array}{c}\text { Hasil } \\
\text { Perangkingan } \\
\end{array}$ \\
\hline IPrime & A1 & 0,832 \\
\hline Iplan & A2 & 0,92 \\
\hline iPLAN Syariah & A3 & 0,852 \\
\hline UBRich & A4 & 0,852 \\
\hline Gemilang & A5 & 0,69 \\
\hline Generali Flexi Optima & A6 & 0,802 \\
\hline We Flexi Pro & A7 & 0,79 \\
\hline Global Medical Plan & A8 & 0,752 \\
\hline GENSafe & A9 & 0,89 \\
\hline $\begin{array}{l}\text { Asuransi Perlindungan } \\
\text { Kredit }\end{array}$ & A10 & 0,807 \\
\hline $\begin{array}{l}\text { Asuransi Kecelakaan Diri } \\
\text { Mikro }\end{array}$ & A11 & 0,192 \\
\hline Asuransi Kecelakaan Diri & A12 & 0,95 \\
\hline $\begin{array}{l}\text { Asuransi Jiwa Berjangka } \\
\text { Kumpulan }\end{array}$ & A13 & 0,75 \\
\hline $\begin{array}{l}\text { Asuransi Cacat Tetap } \\
\text { Total Kumpulan }\end{array}$ & A14 & 0,89 \\
\hline $\begin{array}{l}\text { Asuransi Kematian dan } \\
\text { Cacat Tetap Karena } \\
\text { Kecalakaan Kumpulan }\end{array}$ & A15 & 0,75 \\
\hline $\begin{array}{l}\text { Asuransi Perwatan } \\
\text { Rumah Sakit dan } \\
\text { Perbedaan Kumpulan }\end{array}$ & A16 & 0,7 \\
\hline $\begin{array}{l}\text { Asuransi Rawat Jalan } \\
\text { Kumpulan }\end{array}$ & A17 & 0,78 \\
\hline $\begin{array}{l}\text { Asuransi Perawatan Gigi } \\
\text { Kumpulan }\end{array}$ & A18 & 0,795 \\
\hline $\begin{array}{l}\text { Asuransi Kacamata } \\
\text { Kumpulan }\end{array}$ & A19 & 0,777 \\
\hline iPENSION & A20 & 0,757 \\
\hline iDARE & A21 & 0,873 \\
\hline UB Pro Plus & A22 & 0,713 \\
\hline iPRO & A23 & 0,81 \\
\hline Provesta Optimum & A24 & 0,785 \\
\hline VIP Pro & A25 & 0,722 \\
\hline
\end{tabular}

Nilai perhitungan untuk setiap produk dengan nilai $\mathrm{V}$, dapat dilihat pada tabel berikut :

\section{TABEL XII. HASIL PERANGKINGAN}

Selanjutnya produk diurutkan dari nilai $\mathrm{V}$ terbesar ke nilai $\mathrm{V}$ terkecil, produk dengan nilai $\mathrm{V}$ terbesar.

Dari hasil perhitungan di atas dapat di temukan lima produk terbaik sesuai hasil dari nilai $\mathrm{V}_{1}-\mathrm{V}_{25}$ dengan nilai sebagai berikut :

\section{TABEL XIII. DATA PRODUK TERBAIK}

\begin{tabular}{|c|c|c|c|}
\hline No & Nama Produk & $\begin{array}{c}\text { Kode } \\
\text { Produk }\end{array}$ & $\begin{array}{c}\text { Hasil } \\
\text { Perangkingan }\end{array}$ \\
\hline 1 & Asuransi Kecelakaan Diri & A12 & 0,95 \\
\hline 2 & Iplan & A2 & 0,92 \\
\hline 3 & $\begin{array}{c}\text { Asuransi Cacat Tetap } \\
\text { Total Kumpulan }\end{array}$ & A14 & 0,89 \\
\hline 4 & GENSafe & A9 & 0,89 \\
\hline 5 & iDARE & A21 & 0,73 \\
\hline
\end{tabular}

\section{KESIMPULAN}

Sesuai dengan hasil penelitian Penentuan Produk Terbaik Pada PT Asuransi Jiwa Generali Menggunakan Metode Simple Additive Weihgting (SAW), maka dapat ditarik kesimpulan, sebagai berikut :

- Didapat 5 (lima) produk asuransi terbaik yang ada di PT Asuransi Jiwa Generali, antara lain: Auransi Kecelakaan Diri, Iplan, Asuransi Cacat Tetap Total Kumpulan, GENSafe dan iDare berdasarkan Objektifitas.

- Metode Simple Additive Weihgting (SAW) dapat mengatasi permasalahan yang ada di PT. Asuransi Jiwa Generali dalam pengambilan keputusan untuk mendapatkan minat produk terbaik, yang nantinya produkproduk tersebut menjadi produk unggulan dari perusahaan, dalam memasarkannya ke pelanggan atau nasabah.

\section{DAFTAR PUSTAKA}

Chintyari, Yananda Eka \& Prihatin, Titin. (2018). Implementasi Metode Simpe Additive Weighting untuk Pemilihan Guru Berprestasi Pada SMP Islam Pondok Duta. Jurnal Ilmu Pengetahuan dan Teknologi Komputer, 3(2), 133-138, E-ISSN: 2527-4864. Url: https://media.neliti.com/media/ publications/227262-implementasimetode-imple-additive-weig-921a48e8.pdf

Frieyadie. (2016). Penerapan Metode Simple Additive Weight (SAW) dalam Sistem Pendukung Keputusan Promosi. Jurnal Pilar Nusa Mandiri, XII(1), 37-4. Url: https://media.neliti.com/media/publications/227474-penerapanmetode-simple-additive-weight-4b140887.pdf

Hismawati \& Hardiyan. (2018). Pengambilan Keputusan Dalam Penerima Bantuan Raskin Dengan Metode Simple Additive Weigthing (SAW), Jurnal Swabumi, 6(2), 110-116. Url: ejournal.bsi.ac.id/ejurnal/index.php/swabumi/article/view/4557

Liesdiana, S. F., \& Mauliana, P. (2017). Sistem Pendukung Keputusan Penentuan Kontrak Kerja Agent Call Center Menggunakan Metode SAW. Jurnal Informatika, 4(1), 76-81. Url: https://ejournal.bsi.ac.id/ejurnal/index.php/ji/article/view/1598/pdf Nuraeni, N. (2018). Perancangan Sistem Informasi Akademik Berbasis Website Pada Madrasah Tsanawiyah Yayasan Fisabillilah Bekasi, 6(2), 104-109. Url: ejournal.bsi.ac.id/jurnal/index.php/swabumi/article/view/4556 
[6] Rusdiansyah. (2017). Analisis Keputusan Menentukan Jurusan Pada Sekolah Menengah Kejuruan Dengan Metode Simple Additive Weighting. Jurnal Techno Nusa Mandiri, 14(1), 49-56. Url: ejournal.nusamandiri.ac.id/ejurnal /index.php/techno/article/view/397
Suparwo, A., Riana, D., \& Sari, R. D. (2017). Pelaksanaan Personal Selling Dalam Pengaruhnya Terhadap Keputusan Pembelian Polis Asuransi, $\quad 1(2), \quad 241-248$ Url: https://ejournal.bsi.ac.id/ejurnal/index.php/ecodemica/article/view/ 2258 